\title{
Effects of Ascorbic Acids on Post-Harvest Longevity of Chrysantemum Cut Flowers
}

\author{
DOI: $10.18196 /$ pt.2019.091.33-40
}

\author{
Kurniawan Budiarto \\ Indonesian Ornamental Crops Research Institute (IOCRI), \\ Jl. Raya Pacet-Ciherang, Pacet Cianjur, West Java (43253), Indonesia \\ Corresponding author, email: bud1arto@yahoo.com
}

\section{ABSTRACT}

Longer vase life of chrysanthemum cut flower is one of preferable quality traits in marketing for growers, retailers and consumers. Several compounds, like ascorbic acid have been reported to be able to prolong the post-harvest quality and longevity of cut flowers. Thus, the purpose of the study was to assess the ascorbic acid effects in several concentrations (0, 100, 200, and 300 ppm) in extending the fresh life of two chrysanthemum cultivars, i.e. cv. Remix (spray) and Yellow Fiji (standard). The results showed that the termination of flower freshness was visually characterized by wilting of leaves and florets and the change in floret color (paler). The supplementation of ascorbic acid solution at the concentrations of 200 and 300 ppm prevented and lengthened leaves and florets turgidity and postponed the wilting up to 2 - 3 days compared to control. At the same concentrations, the solution also slowed down the degradation rates of chlorophyll content on leaves during vase life periods.

Keywords: Ascorbic acid, chlorophyll content, chrysanthemum (Dendranthema grandiflora), freshness, vase life, wilting

\section{ABSTRAK}

LFase segar bunga potong krisan yang lebih lama adalah salah satu ciri kualitas yang baik dalam pemasaran bagi petani, pengecer dan konsumen. Beberapa senyawa, seperti asam askorbat telah dilaporkan dapat memperpanjang kualitas pasca panen dan umur panjang bunga potong. Dengan demikian, tujuan dari penelitian ini adalah untuk menilai efek asam askorbat dalam beberapa konsentrasi (0, 100, 200, dan 300 ppm) dalam memperpanjang kehidupan segar dua kultivar krisan, yaitu cv. Remix (semprotan) dan Yellow Fiji (standar). Hasil penelitian menunjukkan bahwa penghentian kesegaran bunga secara visual ditandai dengan layu daun dan kuntum serta perubahan warna bunga kuntum (paler). Suplementasi larutan asam askorbat pada konsentrasi 200 dan 300 ppm mencegah dan memperpanjang turgiditas daun dan kuntum dan menunda layu hingga 2 - 3 hari dibandingkan dengan kontrol. Pada konsentrasi yang sama, larutan asam askorbat juga memperlambat laju degradasi kandungan klorofil pada daun selama periode fase segar.

Kata Kunci: Asam askorbat, kandungan Klorofil, Krisan (Dendranthema grandiflora), Kesegaran, Fase segar, Layu

\section{INTRODUCTION}

Chrysanthemum (Dendranthema gradiflora [Ramat.] Kitam.) is one of famous ornamental cut flowers in almost all parts of the world, including Indonesia. Longer vase life of chrysanthemum cut flower is one of preferable quality traits in marketing for growers, retailers and consumers (Bayat, Aminifard, 2017). Various preservative solutions containing antibiotics (bactericide and/ or fungicide), growth regulators, inhibitors like ethylene or abscisic acid, carbohydrates (Clark et al., 2010; Dole, Carlson, Crawford, \& McCall, 2013; Elbimabi, 2011), and mineral compounds (Banjaw, 2017) are commonly employed to prevent the wilting, thus prolong the cut flower fresh life.

The termination of fresh life is indicated by wilting (Azizi, Onsinejad, \& Kaviani, 2015). Wilting of leaves and florets are mostly generated by imbalance between water and mineral supply and loss due to the resistance of water flow in the stem (Ahmad, Dole, \& Blazich, 2014; Satoh, Nukui, \& Inokuma, 2005; In, Seo, \& Lim, 2016). Water facilitates the chemical reaction within the cell to keep biological activities and maintain cell turgor and flower freshness (Dung, Seaton, \& Singh, 2016; Soleiman-Fard, Hemmati, \& Khalighi, 2013).

The inhibition of water flow within the stem is caused by several factors, i.e. water trapped within membrane cells generally filled with air (embolism) (Van Ieperen, Van Meeteren, \& Nijsse, 2002), physical injuries leading to tissue decay(Wang, Zheng, \& Xu, 2014)and water blockage due to microorganism activities (Kazemi \& Ameri, 2012; Nemati, Tehranifar, Esfandiari, \& Rezaei, 2013). Among these factors, microorganism activities 
resulting the tissue decay was the most common causes of water blockage (Hashemabadi, Kaviani, Shirinpour, \& Zahiri, 2013; Hashemabadi, 2014; Liu, Ratnayake, Joyce, He, \& Zhang, 2012; Jowkar, Kafi, Khalighi, \& Hasanzadeh, 2012). The activities of microorganism produce ethylene and toxic compounds that induce the acceleration of senescence (Basiri, Zarei, Mashayekhy, \& Pahlavany, 2011; Rahman, Ahmad, \& Lgu, 2012; Bhaskar, Rao, \& Reddy, 2017). These processes result in the loss of cell turgor and tissue wilting (Sudaria, Uthairatanakij, \& Nguyen, 2017),

Ascorbic acid (vitamin C) has been reported to have impact on the increase of water uptake in cut flower and prolong vase life of cut flower (Abdulrahman, Ali, \& Faizi, 2012). Several authors also reported that ascorbic acid has played important roles in some biochemical activities as an enzyme cofactor (Szarka, Bánhegyi, \& Asard, 2013), electron transport (Ivanov, 2014) and antioxidant on chloroplast cell membrane (Gallie, 2013). Endogenous ascorbic acid also prevents and maintains issues from oxidative damages due to tissue decay and microorganism activities (Ghadimian \& Danaee, 2015). The supplementation of ascorbic acid solution has been observed to induce the increase of endogenous ascorbic acid content within the stem, thus lengthen the vase life of several cut flowers, i.e. lisianthus (Azizi et al., 2015), snapdragon (Abdulrahman et al., 2012), gerbera (Mehdikhah, Onsinejad, \& Hashemabadi, 2016), and gladiolus (Ravanbakhsh, Mobasser, \& Hasandokht, 2016). The purpose of the study was to evaluate the effects of ascorbic acid at several concentrations on extending the fresh life of spray and standard chrysanthemum cut flowers.

\section{MATERIALS AND METHODS}

Sample Preparation

The study was conducted in the Indonesian Ornamental Crops Research Institute (IOCRI), located at1100 masl, from January to May 2017. A factorial experiment was arranged in completely randomized design with three replications. The first factor was chrysanthemum cultivars, namely cv. Yellow Fiji (standard type) and cv. Remix (spray type) and the second factor was the ascorbic acid concentrations, i.e. 0 (control), 100, 200, and 300 ppm.

\section{Treatment application}

The ascorbic acid (L-ascorbic acid, PubChem 54670067 ) was weighed at 100,200 , and $300 \mathrm{mg}$ and each was put into $100 \mathrm{ml}$ aquadest (distilled water) and stirred for 10 minutes. The solutions were made just before the experimental was set up (freshly mixed). The solutions were then separately put into vase flasks based on the experimental set up with the volume of $300 \mathrm{ml}$ per flask.

\section{Sample collection and observation}

The chrysanthemum flowers were harvested in the morning. The stem was cut and leaved $40 \mathrm{~cm}$ stalk from the terminal flowers. The basal stalks were then dipped into flasks containing $300 \mathrm{ml} /$ flask of ascorbic acids solutions according to the experimental set up. The flasks were arranged in certain distance to facilitate the flowers not in contact with each others. The experimental set up was conditioned in an ambient temperature room with proper aeration and protected from direct sunlight. During the night, artifical lights were provided using 22 watt LED lamps that were put $3 \mathrm{~m}$ above the treated flower stalks.

The variables observed included: (1) duration of leaves freshness, counted as number of days from the first day of treatment application until the leaves were defined wilting, (2) duration of floret freshness, referred to number of days from the first day of treatment application until the outer most florets were defined wilting, (3) floret color, observed using RHS color chart at the first 


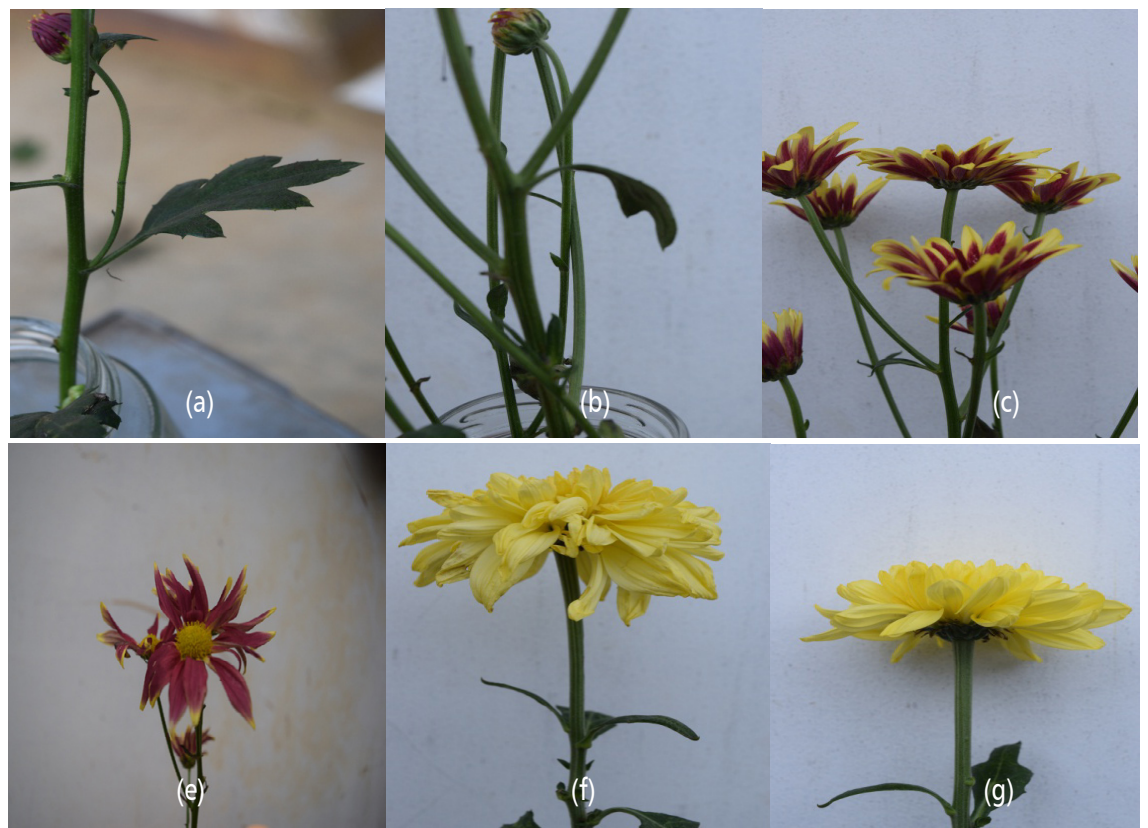

Figure 1. (a) Initial leaf freshness, (b) wilted leaves, (c) Initial and (d) wilted flower of cv. Remix, (e) initial and (f) wilted flower of cv. Yellow Fiji

day of treatment application and the day when the ity. Fresh leaves and florets have an optimal cell florets were defined wilting and (4) chlorophyll turgor. With optimum cell turgor, the position content, measured using portable chlorophyll of leaf and floret blade is seated straight or has an meter SPAD (Konica Minolta). The observations upward angle from the base (Figure 1a, c and e). were conducted every two days starting from the The termination of leaf and floret freshness were first day of treatment application. Two healthy, characterized by the irreversible loss of cell turgor fully expanded, vegetative leaves were selected for resulted in the wilting of leaves and florets (Figure chlorophyll content measurement. The reading values were recorded and converted into predicted $1 b, d$ and $f$ ).

In both chrysanthemum cultivars, the cessation values of chlorophyll content using the equation from Davies, He, Chau, Heinz, \& Cartmill (2004): $\mathrm{y}=0.001 \times 3+0.0104 \times 2-1,730 \mathrm{x}+11.702(\mathrm{r}=$ 0.98), where $y=$ predicted chlorophyll content $(\mu \mathrm{g} /$ $\mathrm{cm}^{2}$ ) and $\mathrm{x}=$ SPAD reading value.

\section{Data analysis}

of flower freshness affected the floret colors. The color of wilted florets in both cultivars displayed the same pattern when wilting in all ascorbic acid concentrations (Table 1). These indicated that the ascorbic acid did not direct the color change into certain color type. The changes of flower color when wilting during vase life were also reported

The collected data were analyzed using ANOVA and subjected to Least Significant Difference (LSD, $\alpha=5 \%)$ test.

\section{RESULTS AND DISCUSSION}

Characteristic of wilting and floret color change

The wilting of leaf and flower was determined by visual observation on leaf and floret turgidon orchid (Khan, Mehraj, Taufique, Ahsan, \& Jamaluddin, 2015), gerbera (Heidarnezhadian, Eghbali, \& Kazemi, 2017), rose (Zamani, Kazemi, \& Aran, 2011) and carnation (Kazemi, Gholami, $\&$ Bahmanipour, 2012). The change of floret color was associated with the decreased carbohydrate content used for respiration and supply due to low photosynthetic rates during vase life period 
Table 1. Initial and wilted floret color of chrysanthemum cv. Yellow Fiji and cv. Remixduring vase life

\begin{tabular}{|c|c|c|}
\hline \multirow{2}{*}{ Chrysanthemum cultivar } & \multicolumn{2}{|c|}{$\begin{array}{c}\text { Floret color } \\
\text { (RHS color chart) }\end{array}$} \\
\hline & Initial & When wilting \\
\hline Yellow Fiji & Yellow 12 B & Yellow 6 B \\
\hline Remix & Red Purple 59 B & Greyed Purple $187 \mathrm{C}$ \\
\hline
\end{tabular}

Table 2. Leaf and flower freshness of two chrysanthemum cut flower cultivars supplemented with ascorbic acid solution at different concentrations

\begin{tabular}{|c|c|c|}
\hline \multirow[t]{2}{*}{ Treatments } & \multicolumn{2}{|c|}{$\begin{array}{c}\text { Duration of } \\
\text { freshness*) (days) }\end{array}$} \\
\hline & Leaves & Flowers \\
\hline \multicolumn{3}{|l|}{ Chrysanthemum cultivars } \\
\hline cv. Remix & $11.11 \mathrm{a}$ & $13.76 \mathrm{a}$ \\
\hline cv. Yellow Fiji & $11.44 \mathrm{a}$ & $13.72 \mathrm{a}$ \\
\hline \multicolumn{3}{|l|}{ Concentration of ascorbic acid (ppm) } \\
\hline 0 (control) & $10 \mathrm{a}$ & $11.67 \mathrm{a}$ \\
\hline 100 & $10.55 a b$ & $13.84 \mathrm{~b}$ \\
\hline 200 & $12.5 \mathrm{~b}$ & $14.57 \mathrm{~b}$ \\
\hline 300 & $12.05 \mathrm{~b}$ & 14.89 \\
\hline \multicolumn{3}{|l|}{ Treatment combinations } \\
\hline cv. Remix in 0 ppm ascorbic acid (control) & $10 \mathrm{a}$ & 11.67 a \\
\hline cv. Remix in 100 ppm ascorbic acid & $10.55 \mathrm{a}$ & $13.57 \mathrm{ab}$ \\
\hline cv. Remix in 200 ppm ascorbic acid & $12.11 \mathrm{~b}$ & $14.8 \mathrm{~b}$ \\
\hline cv. Remix in 300 ppm ascorbic acid & $11.77 \mathrm{ab}$ & $15 b$ \\
\hline cv. Yellow Fiji in 0 ppm ascorbic acid (control) & $10 \mathrm{a}$ & 11.67 a \\
\hline cv. Yellow Fiji in 100 ppm ascorbic acid & $10.55 \mathrm{a}$ & $14.1 \mathrm{~b}$ \\
\hline cv. Yellow Fiji in 200 ppm ascorbic acid & $12.89 \mathrm{~b}$ & $14.33 \mathrm{~b}$ \\
\hline cv. Yellow Fiji in 300 ppm ascorbic acid & $12.33 \mathrm{~b}$ & $14.77 \mathrm{~b}$ \\
\hline
\end{tabular}

Remarks: *)*) Values in the same column under each criterion of cultivars, ascorbic acid concentrations and treatment combinations followed by different letters differ significantly based onLeast Significant Different test (LSD, $\alpha \leq 5 \%)$.

(Ichimura, 1998). Carbohydrate was one of the main compounds in pigment biosynthesis process and other secondary metabolites, including anthocyanins (Khan et al., 2015; Heidarnezhadian et al., 2017; Zamani et al., 2011). However, ascorbic acid was predicted to have relation in slowing down the process of color change along with the induction of prolonged flower freshness during vase life.

\section{Leaf and floret fresh life period}

Analysis of variance on the effects of ascorbic acid solution at several concentrations as holding solution for cut flowers of two chrysanthemum cultivars revealed that there was no significant interaction effect between ascorbic acid concentrations and chrysanthemum cultivars on lifespan of leaf and floret longevity. The duration of flower freshness of both tested cultivars was not significantly different (Table 2). This condition inferred that both chrysanthemum cultivars that have different genetic backgrounds performed similar retention on the duration of flower freshness. Similar findings were also reported by Baskaran, Jayanthi, Janakiram, \& Abirami (2010)and Sharma $\&$ Srivastava (2014) on the observation of vase life of several chrysanthemum cultivarswith or without chemical supplements.

Table 2 showed that the lifespan of leaf and flower freshness were also affected by the application of ascorbic acid. The cut flowers supplemented with ascorbic acid solution had prolonged leaf and flower freshness. The longest leaf freshness was observed on the cut flower dipped in 200 ppm ascorbic acid solution with the average of 2.5 days longer than control. At higher concentration (300 ppm), however, the effects were descended. Different phenomena were observed in petal freshness. The prolonged petal freshness was induced in lower ascorbic acid concentration. Longer period of petal freshness, in average of 2 days, was observed in chrysanthemum cut flower supplemented with 100 ppm. At higher concentrations (200 and 300 ppm), the induction of prolonged petal freshness was not significant.

After the flowers were harvested (the stem was cut) and during vase life period, the photosynthetic activities continued with diminished rates. The flower stalks use carbohydrate storage within the organ tissues for respiration to support cells' life 

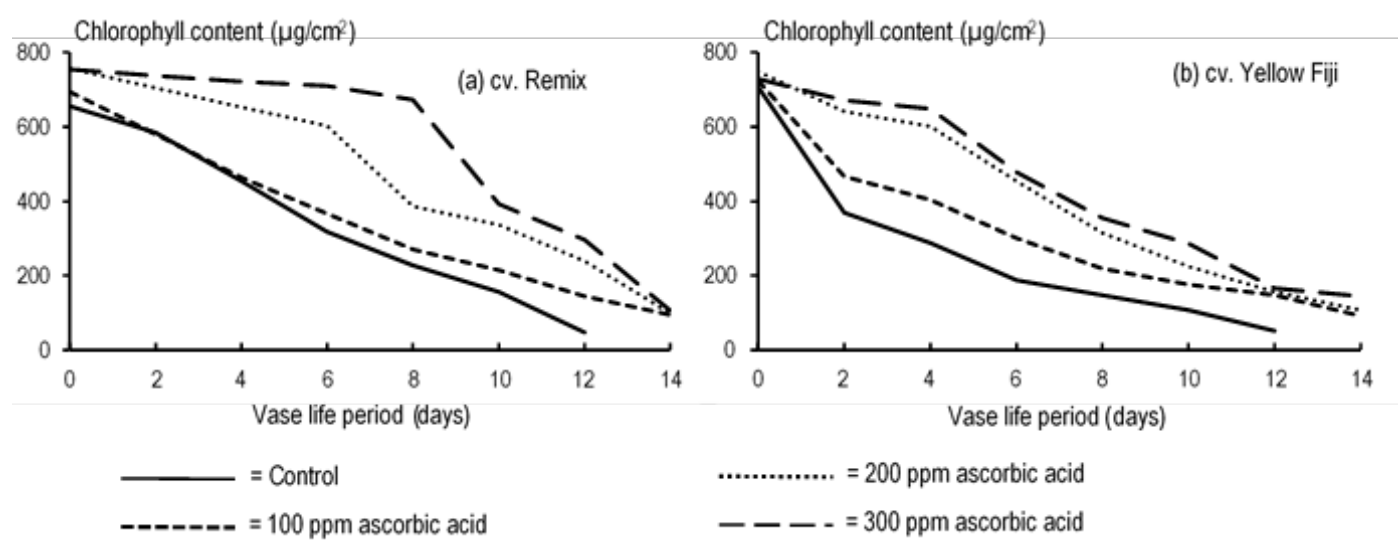

Figure 2. Chlorophyll content in the leaves of chrysanthemum cut flower stem cv. Remix (left) and Yellow Fiji (right) treated by ascorbic acid solution in various concentrations during vase life period.

(Hossain, Boyce, \& Majid, 2008). During vase life, ascorbic acid is needed to prevent leaf wilting, thus maintain the water balance and photosynthetic activities (Forti \& Elli, 1995; Kobayakawa \& Imai, 2012)although in lower rates. This mechanism is predicted to have relation with higher concentration of ascorbic acid needed to prolong leaves and petals freshness. These phenomena were detected on both tested cultivars cv. Yellow Fiji and cv. Remix (Table 2).

Several studies reported that ascorbic acid prolonged the flower longevity through several mechanisms. Ascorbic acid might be lowering the respiration rate and ethylene synthesis (Abri, Ghasemmezhad, Hasansajedi, \& Bakhshi, 2013). The low respiration infers the ability of flower stalk to minimize water loss and maintain water content through active metabolic process (Abdulrahman et al., 2012). Ascorbic acid plays important role in improving water uptake by depleting the stem resistance. The antimicrobial characteristics of the substance delay the tissue decay and maintain tissue-water conductivity within the stem, thus increase water uptake by the basal stem (Bhaskar et al., 2017).

\section{Chlorophyll content}

The chlorophyll content gradually decreased based on every two day-SPAD measurements in all treated cut flowers during the vase life period (Figure 2). Sharper chlorophyll decrease was detected on the cut flower leaves of control treatment. The decrease of chlorophyll content indicates chlorophyll degradation (Basiri et al., 2011) which is generally caused by mineral translocation and microorganism activities (Elhindi, 2012). Without ascorbic acid supplement, the chlorophyll degradation is predicted to be faster. The faster chlorophyll degradation on control treatment was detected on both tested cultivars. The measurement of chlorophyll content on control treatment was terminated after 14 days since the leaves had wilted and dried.

The decrease of chlorophyll content on the leaves of cut flowers treated by ascorbic acid solution were slower especially after 4 (cv. Yellow Fiji) and 8 (cv. Remix) days during vase life period (Figure 2). On both tested cultivars, the highest chlorophyll content (slowest chlorophyll degradation) was detected on cut flower treated with 300 ppm, followed by 200 and 100 ppm ascorbic acids treatments. The slow chlorophyll degradation is related with lower respiration rate and the increase of water uptake of cut flower (Balouchi, Peyvast, Ghasemnezhad, \& Dadi, 2012). This condition is predicted due to the preservative effect of ascorbic acid in preventing water blockage in the transport tissues (Banaee, Hadavi, \& Moradi, 2013), thus prolong the flower freshness during vase life period. 
Based on the SPAD chloropyll measurements, the increase of chlorphyll content was not detected in any ascorbic acid concentrations during vase life period. The application of ascorbic acid solution affected only chlorophyll retention thus slowed down the chlorophyll degradation. These phenomena are not in line with the findings of Ghadimian \& Danaee (2015) on roses and Asrar (2012) on snapdragon, in which ascorbic acid treatments increased the chlorophyll content of the cut flowers during vase life. Further evaluations on the effect of ascorbic acid at higher concetrations with and/or without other synegistic preservatives supplements are needed to improve chlorophyll content of cut flower during vase life, thus prolong the flower longevity.

\section{CONCLUSIONS}

Termination of chrysanthemum cut flower freshness was characterized by the wilting of leaves and florets and the change of floret color (less colored) on both tested chrysanthemum cultivars, cv. Remix and Yellow Fiji. Supplementation of ascorbic acid at concentration of 200 to 300 ppm delayed the leaf and petal wilting up to 2 to 3 days compared to control (without ascorbic acid) treatment. At the same concentrations, ascorbic acid treatments also slowed down chlorophyll degradation during vase life period.

\section{ACKNOWLEDGMENTS}

The authors would like to thank to the Indonesian Agency for Agricultural Research and Development (IAARD), Center for Horticultural Research and Development (ICHORD), Indonesian Ornamental Crops Research Institute (IOCRI) that provided funding for the research. The authors would also like to thank Mr. Agus Sutisna, Reno Rosmariono, Ujang, Laely Qodriyah and all of supporting members during observation and data collection.

\section{REFERENCES}

Abdulrahman, Y. A., Ali, S. F., \& Faizi, H. S. (2012). Effect of sucrose and ascorbic acid concentrations on vase life of snapdragon (Antirrhinum majus L.) cut flower. International Journal of Pure and Applied Sciences and Technology, 13(2), 32-41.

Abri, F., Ghasemmezhad, M., Hasansajedi, R., \& Bakhshi, D. (2013). Effect of ascorbic acid on vase life and petal senescence in cut rose flowers (Rosa hybrida) cv. "Royal Class." American-Eurasian Journal of Agricultural \& Environmental Sciences, 13(1), 38-43. https://doi.org/10.5829/idosi.aejaes.2013.13.01.1901.

Ahmad, I., Dole, J. M., \& Blazich, F. A. (2014). Effects of daily harvest time on postharvest longevity, water relations, and carbohydrate status of selected specialty cut flowers. HortScience, 49(3), 297-305.

Asrar, A. W. A. (2012). Effects of some preservative solutions on vase life and keeping quality of snapdragon (Antirrhinum majus L.) cut flowers. Journal of the Saudi Society of Agricultural Sciences, 11(1), 29-35. https://doi.org/10.1016/j. jssas.2011.06.002.

Azizi, S., Onsinejad, R., \& Kaviani, B. (2015). Effect of ascorbic acid on post-harvest vase life of cut Lisianthus (Eustoma grandiflorum L.) flowers. ARPN Journal of Agricultural and Biological Science, 10(11), 417-420.

Balouchi, Z., Peyvast, G.-A., Ghasemnezhad, M., \& Dadi, M. (2012). Effects of ascorbic acid in delaying florets senescence of broccoli during post-harvest storage. South Western Journal of Horticulture Biology and Environment, 3(2), 167-183. Retrieved from http://anucraiova.3x.ro/swjhbe/index.html.

Banaee, S., Hadavi, E., \& Moradi, P. (2013). Effect of ascorbic acid, 8-hydroxyquinoline sulfate and sucrose on the longevity and anthocyanin content of cut gerbera flowers. Current Agriculture Research Journal, 1(1), 29-33. https://doi.org/10.12944/ CARJ.1.1.03.

Banjaw, D. T. (2017). Review on effect of essential oil on vase life of cut flowers. Research \& Reviews : Journal Od Agriculture and Allied Science, 6(1), 14-17.

Basiri, Y., Zarei, H., Mashayekhy, K., \& Pahlavany, M. H. (2011). Effect of rosemary extract on vase life and some qualitative characteristics of cut carnation flowers (Dianthus carryophyllus cv. White Librity). Journal of Stored Products and Postharvest Research, 2(14), 261-265.

Baskaran, V., Jayanthi, R., Janakiram, T., \& Abirami, K. (2010). Evaluation of post harvest quality of some cultivars of chrysanthemum. Journal of Horticultural Science, 5(1), 81-83.

Bayat, H., \& Aminifard, M. H. (2017). Salicylic acid treatment extends the vase life of five commercial cut flowers. Electronic Journal of Biology, 13(1), 67-72.

Bhaskar, V. V., Rao, P. V., \& Reddy, R. S. (2017). Effect of different chemicals on the microbial growth during vase life period of cut rose cv . 'First Red.' International Journal of Current Microbiology and Applied Science, 6(10), 812-820. https://doi. org/10.20546/ijcmas.2017.610.097.

Clark, E. M. R., Dole, J. M., Carlson, A. S., Moody, E. P., McCall, I. F., Fanelli, F. L., \& Fonteno, W. C. (2010). Vase life of new cut flower cultivars. HortTechnology, 20(6), 1016-1025. Retrieved from http://horttech.ashspublications.org/content/20/6/1016. abstract. 
Davies, F. T., He, C., Chau, A., Heinz, K. M., \& Cartmill, A. D. (2004). Fertility affects susceptibility of chrysanthemum to cotton aphids : Influence on plant growth, photosynthesis, ethylene evolution, and herbivore abundance. Journal of the American Society for Horticultural Science, 129(3), 344-353.

Dole, J. M., Carlson, A. S., Crawford, B. D., \& McCall, I. F. (2013). Vase life of new cut flowers. Acta Horticulturae, (1000), 63-70. https://doi.org/10.17660/ActaHortic.2013.1000.6.

Dung, C. D., Seaton, K., \& Singh, Z. (2016). Factors affecting variation in the vase life response of waxflower cultivars (Myrtaceae: Chamelaucium Desf. and Verticordia spp. Desf.) tested under various vase solutions. Folia Horticulturae, 28(1), 41-50. https://doi.org/10.1515/fhort-2016-0006

Elbimabi, M. E. N. E. (2011). Vase life extension of rose cut flowers as influenced by silver nitrate and sucrose pulsing. American Journal of Agricultural and Biological Sciences, 6(1), 128-133.

Elhindi, K. M. (2012). Evaluation of several holding solutions for prolonging vase-life and keeping quality of cut sweet pea flowers (Lathyrus odoratus L.). Saudi Journal of Biological Sciences, 19(2), 195-202. https://doi.org/10.1016/j.sjbs.2011.12.001.

Forti, G., \& Elli, G. (1995). The function of ascorbic acid in photosynthetic phosphorylation. Plant Physiology, 109(4), 1207-1211. https://doi.org/10.1104/pp.109.4.1207.

Gallie, D. R. (2013). L-Ascorbic acid: A multifunctional molecule supporting plant growth and development. Scientifica, 1-25. https://doi.org/10.1155/2013/795964.

Ghadimian, S., \& Danaee, E. (2015). Influences of ascorbic acid and salicyllic acid on vase life of cut flowers rose (Rosa hybrida cv. Black Magic). International Journal of Biology, Pharmacy and Allied Sciences, 5(1), 297-305.

Hashemabadi, D. (2014). The role of silver nano-particle and silver thiosulfate on the longevity of cut carnation (Dianthus carryophyllus) flowers. Journal of Environmental Biology, 35, 661-666.

Hashemabadi, D., Kaviani, B., Shirinpour, A., \& Zahiri, S. (2013). Effects of copper nano-particles (CNPs) on vase life of cut flowers chrysanthemum (Chrysanthemum morifolium L. 'White'). European Journal of Experimental Biology, 3(6), 153-155.

Heidarnezhadian, H., Eghbali, B., \& Kazemi, M. (2017). Postharvest life of cut gebera flowers as affected by salicylic acid and citric acid. Trakia Journal of Science, 15(1), 27-29. https://doi. org/10.15547/tjs.2017.01.005.

Hossain, A. B. M. S., Boyce, A. N., \& Majid, H. M. A. (2008). Vase life extension and chlorophyll fluorescence yield of bougainvillea flower as influenced by ethanol to attain maximum environmental beautification as ornamental components. American Journal of Environmental Sciences, 4(6), 625-630. https://doi. org/10.3844/ajessp.2008.625.630.

Ichimura, K. (1998). Improvement of postharvest life in several cut flowers by the addition of sucrose. JARQ-Japan Agricultural Research Quarterly, 32(4), 275-280.

In, B. C., Seo, J. Y., \& Lim, J. H. (2016). Preharvest environmental conditions affect the vase life of winter-cut roses grown under different commercial greenhouses. Horticulture Environment and Biotechnology, 57(1), 27-37. https://doi.org/10.1007/ s13580-016-0106-9.

Ivanov, B. N. (2014). Role of ascorbic acid in photosynthesis. Bio- chemistry (Moscow), 79(3), 364-372.

Jowkar, M. M., Kafi, M., Khalighi, A., \& Hasanzadeh, N. (2012). Postharvest physiology and microbial impact of hydroxy quinoline citrate as "Cherry Brandy" rose vase solution biocide. Annals of Biological Research, 3(5), 2238-2247.

Kazemi, M., \& Ameri, A. (2012). Postharvest life of cut gerbera as affected by nano-silver and acetylsalicylic acid. Asian Journal of Biochemistry, 7(2), 106-111. https://doi.org/10.3923/ ajb.2012.106.111.

Kazemi, M., Gholami, M., \& Bahmanipour, F. (2012). Effect of silicon and acetic acid on antioxidant activity, membrane stability and ACC-oxidase activiy in relation to vase life of carnation cut flower. Biotechnology, 11(2), 87-90. https://doi.org/10.3923/ biotech.2012.87.90.

Khan, P., Mehraj, H., Taufique, T., Ahsan, N., \& Jamaluddin, A. F. M. (2015). Vase life and keeping qulaity of Dendrobium orchid (Dendrobium sp.) on preservative solutions. International Journal of Experimental Agriculture, 5(3), 22-27.

Kobayakawa, H., \& Imai, K. (2012). Methyl jasmonate affects $\mathrm{O}_{3}$ inhibiton of photosynthesis and ascorbic acid content in paddy rice grown at different $\mathrm{CO}_{2}$ concentrations. Environmental Control in Biology, 50(4), 335-345.

Liu, J., Ratnayake, K., Joyce, D. C., He, S., \& Zhang, Z. (2012). Effects of three different nano-silver formulations on cut Acacia holosericea vase life. Postharvest Biology and Technology, 66, 8-15. https://doi.org/10.1016/j.postharvbio.2011.11.005.

Mehdikhah, M., Onsinejad, R., \& Hashemabadi, D. (2016). Postharvest life of cut gerbera (Gerbera jamesonii) flowers as affected by salicylic acid, citric acid and ascorbic acid, 11(5), 170-174.

Nemati, S. H., Tehranifar, A., Esfandiari, B., \& Rezaei, A. (2013). Improvement of vase life and postharvest factors of Lilium orientalis 'Bouquet' by silver nano particles. Notulae Scientia Biologicae, 5(4), 490-493. https://doi.org/10.15835/ NSB.5.4.9135.

Rahman, M. M., Ahmad, S. H., \& Lgu, K. S. (2012). Psidium guajava and Piper betle leaf extracts prolong vase life of cut carnation (Dianthus caryophyllus) flowers. The Scientific World Journal, 102805, 1-9. https://doi.org/10.1100/2012/102805.

Ravanbakhsh, A., Mobasser, H. R., \& Hasandokht, M. R. (2016). Efefct of ascorbic acid and acetyl salicylic acid on the quality and vase life of cut flower gladiolus (Gladiolus persicus). International Journal of Agriculture and Bioscience, 6(1), 31-33. https://doi. org/10.4081/ijas.2012.e77.

Satoh, S., Nukui, H., \& Inokuma, T. (2005). A method for determining the vase life of cut spray carnation flowers. Journal of Applied Horticulture, 7(1), 8-10.

Sharma, G., \& Srivastava, R. (2014). Post-harvest life of cut chrysanthemum cultivars in relation to chemicals, wrapping material and storage conditions. Tropical Agricultural Research, 26(1), 195-201. https://doi.org/10.4172/2376-0354.1000123.

Soleiman-Fard, E., Hemmati, K., \& Khalighi, A. (2013). Improving the keeping quality and vase life of cut Alstroemeria flowers by pre and post-harvest salicylic acid treatments. Notulae Scientia Biologicae, 5(3), 364-370. https://doi.org/10.15835/ NSB.5.3.9095.

Sudaria, M. A., Uthairatanakij, A., \& Nguyen, H. T. (2017). Postharvest quality effects of different vaselife solutions on cut rose (Rosa 
Planta Tropika: Jurnal Agrosains (Journal of Agro Science) Vol. 7 No. 1 / February 2019

hybrida L.). International Journal of Agriculture, Forestry and Life Science, 1(1), 12-20.

Szarka, A., Bánhegyi, G., \& Asard, H. (2013). The inter-relationship of ascorbate transport, metabolism and mitochondrial, plastidic respiration. Antioxidants \& Redox Signaling, 00(00), 1-8. https://doi.org/10.1089/ars.2012.5059.

Van leperen, W., Van Meeteren, U., \& Nijsse, J. (2002). Embolism repair in cut flower stems: $A$ physical approach. Postharvest Biology and Technology, 25(1), 1-14. https://doi.org/10.1016/ S0925-5214(01)00161-2.

Wang, R., Zheng, X., \& Xu, X. (2014). Evidence for physiological vascular occlusion in stems of cut gerbera cv. Hongyan. Journal of Agricultural Science and Technology, 16(2), 365-372.

Zamani, S., Kazemi, M., \& Aran, M. (2011). Postharvest life of cut rose flowers as affected by salicylic acid and glutamin. World Applied Sciences Journal, 12(9), 1621-1624. https://doi. org/10.15547/tjs.2017.01.005. 